\title{
Factors affecting in sacco degradation of dry matter and crude protein in grass silage
}

\author{
JOUKO SETÄLÄ ${ }^{1}$, ALEM TESFA $^{2}$, AINO RAURAMAA ${ }^{1}$ \\ and ESKO POUTIAINEN ${ }^{3}$
}

1 Valio Finnish Co-operative Dairies' Association, Research and Development Department, Kalevankatu 56, P.O. Box 176, SF-00181 Helsinki, Finland

${ }^{2}$ University of Helsinki, Department of Animal Husbandry, SF-00710 Helsinki, Finland

${ }^{3}$ Agricultural Research Center, 31600 Jokioinen, Finland

\begin{abstract}
The degradability of dry matter and crude protein was studied in 96 grass silages, which were collected from practical farms in different parts of Finland. The degradabilities were determined by the nylon bag technique in sheep on a grass silage and hay $(50: 50$ on DM basis) -based diet.

Among chemical components the $\mathrm{N}$-free extracts increased, and the crude fibre decreased the dry matter degradation in the rumen. The correlation between the end-products from silage fermentation and the dry matter degradability was generally negative. The level of the crude protein degradability was significantly increased when the crude protein content in the silage DM was increased. The amount of $\mathrm{NO}_{3}$ in the silage DM had a similar effect. The rate of crude protein degradation was regulated mainly by the proteolysis in the silage, e.g. the amounts of $\mathrm{NH}_{3}$ and especially water soluble $\mathrm{N}$ in the total $\mathrm{N}$ of silage. Crude fibre tended to protect crude protein against ruminal digestion.
\end{abstract}

\section{Introduction}

Grass is the most potential feed with reasonably high energy and protein contents, which can successfully be grown and harvested for silage also in the northern countries. Factors affecting the energy and protein value of grass silage have intensively been studied in many countries. Some of the experimental results in Finland have shortly been reviewed by Setàla (1984).
The increase in the knowledge concerning the protein metabolism and requirements of a ruminant has drawn attention to the importance of the feed energy and protein degradability in the rumen. This regards also grass silage. The aim of the present study was to investigate factors affecting ruminal degradability of the dry matter and crude protein of the silage. In order to receive the most realistic data, experimental material was collected from practical farms.

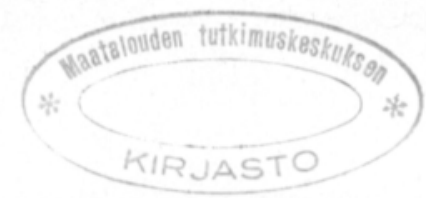




\section{Material and methods}

The material included 96 grass silage samples which were collected from practical farms in 1981 in different parts of Finland. The silages were unwilted and preserved mainly with the AIV-solutions (Valio, Finnish Co-operative Dairies' Association), which contain either formic acid $(80 \%)$ and orthophosphoric acid $(2 \%)$ as AIV II, or formic acid (27 \%) and $\mathrm{HCl}(22 \%)$ as AIV I. AIV II and AIV I were used in $76.5 \%$ and $9.2 \%$ of the silages, respectively. A formaldehyde containing additive (Viher-solution, $55 \%$ formalin, $30 \%$ acetic acid, Farmos Group Ltd) was used in $14.3 \%$ of the silages. The silage samples were immediately frozen on a farm and they were sent to the laboratory in insulated boxes.

The DM content of the silage was calculated after drying at $+80^{\circ} \mathrm{C}$ overnight. For chemical analyses the samples were dried in a vacuum at $+50^{\circ} \mathrm{C}$ for 24 hours, and the dried sample for the analyses was milled through a $1.0 \mathrm{~mm}$ ø screen. Water soluble $\mathrm{N}$ was analyzed after the fresh sample had been extracted in distilled water as described by HUIDA (1973).

The chemical composition of the silages was analyzed by the standard methods. The silage $\mathrm{pH}$ and $\mathrm{NH}_{3}$ were measured in the effluent pressed from the silage (HEIKONEN et al. 1979). The water soluble N (WSN) was ana- lyzed by the Kjeldahl method. The reducing sugars were determined according to SoMOGYI (1945) and the lactic acid and volatile fatty acids using enzymatic (ANON 1980) and gas chromatographic methods, respectively. The analyses of $\mathrm{NO}_{3}$ were made by the ionselective electrode.

The degradabilities of dry matter (DM) and crude protein $(\mathrm{CP})$ were determined by the nylon bag technique (MEHREZ and ØRSKOV 1977) as explained by SETÄLĀ (1983). The tests were made with two sheep on a hay and grass silage diet (1: 1 on DM basis). Fresh silage was chopped to the length of less than $0.5 \mathrm{~cm}$, and 5 grams of silage dry matter was placed in each bag. Five bags were incubated in the rumen at the same time. There was a grass silage sample in four bags and a standard hay sample in one bag. Only one replicate for silage/ incubation period was used and for each silage the incubation was performed during one day. Grass silage samples were incubated for 2, 5, 18 , and 24 hours. A standard hay sample was always incubated for 24 hours and the degradability of dry matter in the hay was used for controlling ruminal fermentations during the incubations.

The degradability of dry matter without crude protein ( $\mathrm{N}$-free $\mathrm{DM}$ ) was also calculated in order to exclude the effect of the crude protein degradation on the DM degradability. The degradability of $\mathrm{N}$-free DM was calculated as follows:

Degradability- $\%=\frac{\left[\mathrm{gDM}_{\text {inc }}-\left(0.01 \times \mathrm{CP}_{\text {inc }} \% \times \mathrm{gDM}_{\text {inc }}\right)\right]-\left[\mathrm{gDM}_{\text {res }}-\left(0.01 \times \mathrm{CP}_{\text {res }} \% \times \mathrm{gDM}_{\text {res }}\right)\right] \times 100}{\left[\mathrm{gDM}_{\text {inc }}-\left(0.01 \times \mathrm{CP}_{\text {inc }} \% \times \mathrm{gDM}_{\text {inc }}\right)\right]}$

$\mathrm{DM}_{\text {inc }}=$ amount of DM incubated (correspondingly $\mathrm{CP}_{\text {inc }}$ )

$\mathrm{DM}_{\text {res }}=$ amount of DM left in the bag after incubation (correspondingly $\mathrm{CP}_{\text {res }}$ )

\section{Results and discussion}

Chemical composition and quality of the silages

The average quality data of the silages showed that the quality of the silages accord- ing to e.g. Heikonen et al. (1979) was relatively good (Table 1). There were, however, great variations between silages if the contents of the reducing sugars and butyric acid are considered. The average crude protein content was lower and the crude fibre content higher 
than the corresponding values in all the silages analyzed in Finland 1981.

The correlations between different chemical components (Table 2) should be regarded as quite typical of grass silages. A high ash content (soil contamination) increased the $\mathrm{pH}$, $\mathrm{NH}_{3}$ (deamination), and butyric acid in the silage. Moreover, high $\mathrm{pH}$ increased proteolysis, deamination $\left(\mathrm{NH}_{3}, \mathrm{WSN}\right)$ and butyrate fermentation. The latter was closely connected to the yields of propionic acid. If it is assumed that a low sugar content of the silage is a sign of a vigorous fermentation in the silo, it could be concluded that a vigorous fermentation increased proteolysis and deamination in the silages. Part of these processes could be explained by a Clostridia fermentation (OHSHIMA and MCDonald 1978) but it must be emphasized that lactic acid fermentation also correlated negatively with the content of the reducing sugars in the present study.

\section{Comparison between the degradability of dry matter and crude protein}

The dry matter and crude protein in the silages degraded at different rates in the rumen

Table 1. The average chemical composition of the silages in the present study and in Finland 1981.

\begin{tabular}{|c|c|c|c|}
\hline & \multicolumn{2}{|c|}{ Present study } & \multirow{2}{*}{$\frac{\text { In Finland }}{1981}$} \\
\hline & $\overline{\mathrm{x}}$ & s.d. & \\
\hline $\mathrm{N}$ & 96 & & 19596 \\
\hline Dry matter, \% & 20.3 & 2.6 & 21.5 \\
\hline \multicolumn{4}{|l|}{$\mathrm{g} / \mathrm{kg} \mathrm{DM}$} \\
\hline Ash & 78 & 27 & - \\
\hline Crude protein & 149 & 28 & 156 \\
\hline Crude fibre & 290 & 28 & 277 \\
\hline Reducing sugars & 51 & 51 & - \\
\hline $\mathrm{N}$-free extracts 1 & 482 & 40 & \\
\hline \multicolumn{4}{|l|}{$\mathrm{g} / \mathrm{kg}$} \\
\hline Lactic acid & 10 & 5 & - \\
\hline Lactic + acetic acids & 18 & 6 & - \\
\hline Butyric acid & 0.5 & 1.3 & - \\
\hline Propionic acid & 0.05 & 0.03 & - \\
\hline $\mathrm{pH}$ & 3.9 & 0.3 & $3.9^{2}$ \\
\hline WSN, $\%$ in total $\mathrm{N}$ & 49.3 & 12.2 & - \\
\hline $\mathrm{NH}_{3}, \mathrm{~g} / \mathrm{l}$ pressed juice & 0.4 & 0.3 & $0.4^{2}$ \\
\hline $\mathrm{NO}_{3}, \mathrm{~g} / 1$ pressed juice & 0.5 & 0.3 & - \\
\hline
\end{tabular}

$1 \mathrm{~N}$-free extracts $=100-($ Ash- $\%+$ Crude protein $-\%+$ Crude fibre-\%)

${ }^{2} \mathrm{~N}=13037$

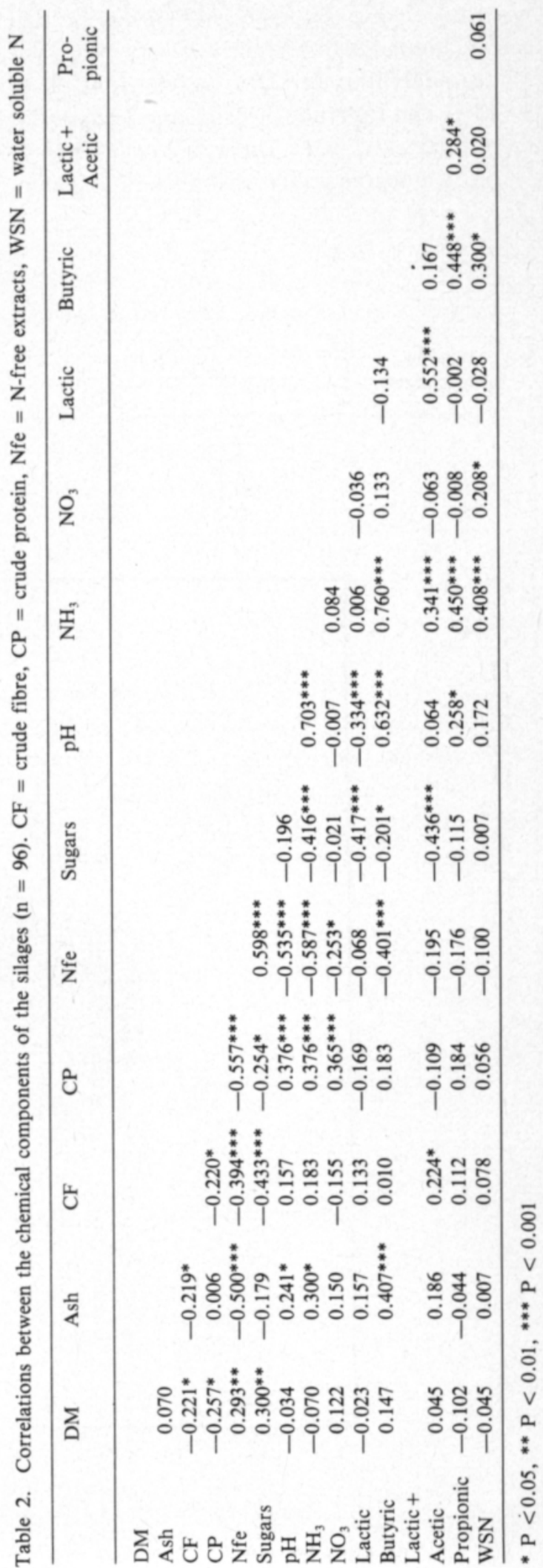


(Table 3, Fig. 1). Especially during the first five hours the difference was very clear. The degradabilities for DM varied from 10 to $42 \%$ and for crude protein from 15 to $75 \%$, respectively (Fig. 1). The variation in the crude protein degradability was much more exten- sive than the variation in the DM degradability. This can have a great effect on the utilization of ruminally degradable silage $\mathrm{N}$. If it is assumed that the organic matter of silage is fermented at a similar rate as the silage DM, and the degradability of DM and crude pro-

Table 3. Degradability-\% of silage DM, N-free DM, and crude protein in sacco ( 96 silages).

\begin{tabular}{|c|c|c|c|c|c|c|}
\hline \multirow{2}{*}{$\begin{array}{l}\text { Incubation } \\
\text { period hours }\end{array}$} & \multicolumn{2}{|c|}{ Dry matter } & \multicolumn{2}{|c|}{$\mathrm{N}$-free DM } & \multicolumn{2}{|c|}{ Crude protein } \\
\hline & $\overline{\mathrm{x}}$ & s.d. & $\overline{\mathrm{x}}$ & s.d. & $\overline{\mathrm{x}}$ & s.d. \\
\hline 2 & 29.3 & 5.6 & 22.3 & 5.6 & 46.5 & 11.3 \\
\hline 5 & 35.6 & 5.7 & 27.4 & 5.8 & 52.5 & 10.4 \\
\hline 18 & 57.6 & 7.0 & 45.9 & 5.9 & 77.1 & 6.1 \\
\hline 24 & 64.4 & 7.1 & 51.7 & 5.8 & 79.5 & 5.1 \\
\hline
\end{tabular}

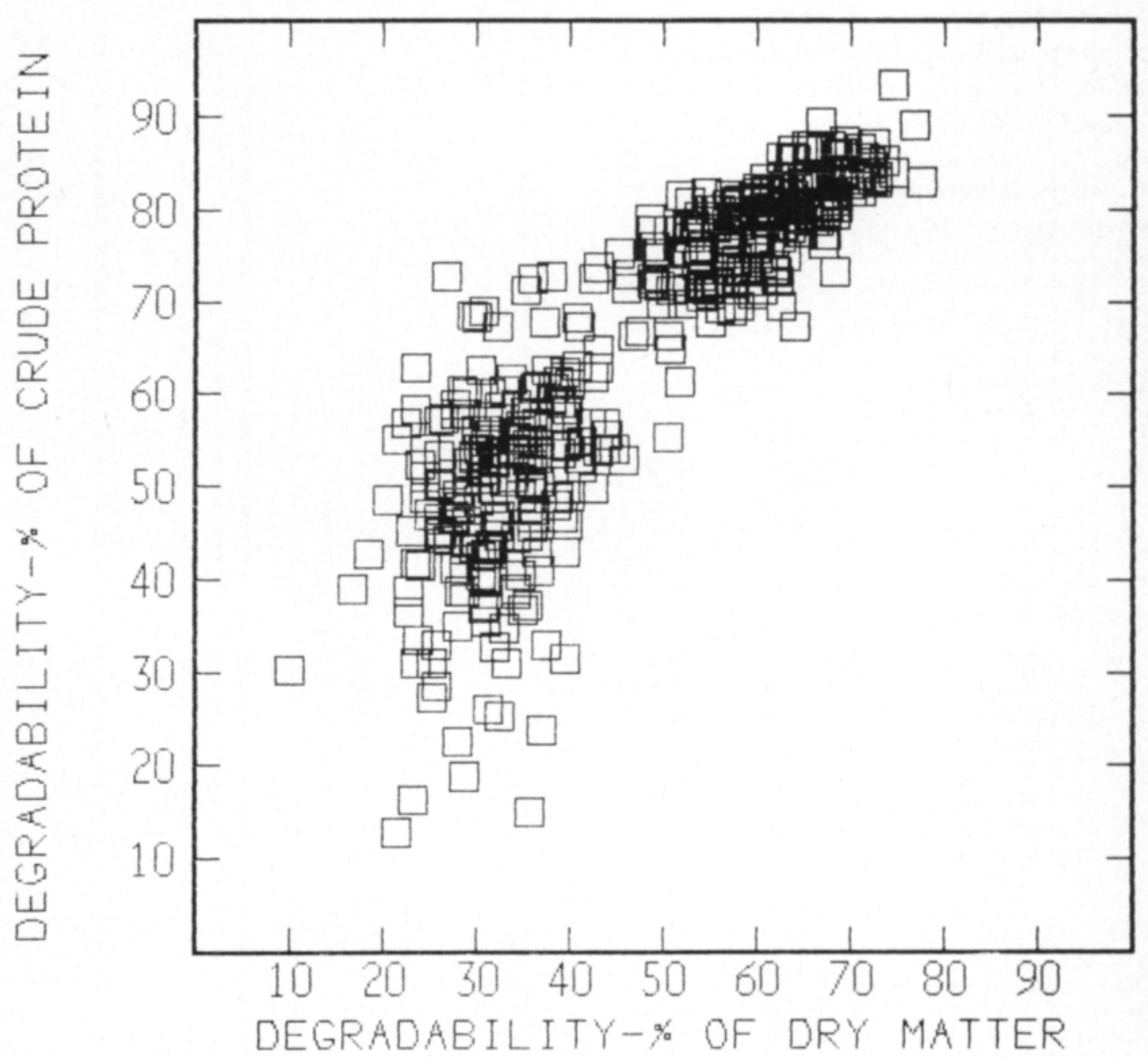

Fig. 1. Comparison between the DM and crude protein degradabilities (from 2 to 24 hours) of the silages. 
tein are correspondingly $42 \%$ and $75 \%$, the ratio of the ruminally degradable $\mathrm{N}$ (RDN) and fermentable organic matter (OMF) would be $4.6 \mathrm{~g} \mathrm{RDN} / 100 \mathrm{~g} \mathrm{OMF}$ in the present material. If it is assumed that the efficiency of the utilization of RDN for microbial protein synthesis is $100 \%$, this value is almost twice as great as suggested for an appropriate value according to the average microbial protein synthesis (2.5 g microbial N/100 g OMF) in grass silage -based diets (Miller 1982, ТнOMAS 1982).

\section{Factors affecting the degradability of dry matter}

The most important factors affecting the DM and $\mathrm{N}$-free DM degradability were the contents of the crude fibre and $\mathrm{N}$-free extracts in the silage DM (Table 4). The $\mathrm{N}$-free extracts include hemicellulose and sugars which can more rapidly and easily be degraded in the rumen than cellulose fraction in crude fibre. On the other hand, crude fibre including cellulose and lignin seemed to protect the silage DM against ruminal digestion.

Regarding the correlations it must be emphasized, that although they were significant (df 94), they accounted only for a very small proportion of the variance. However, the negative correlations between the degradability of $\mathrm{N}$-free $\mathrm{DM}$ and $\mathrm{pH}$ (and $\mathrm{NH}_{3}$ ) or the degradability of DM and lactic + acetic acids might indicate that the highest degradability of DM is obtained when the silage is well preserved without vigorous fermentation and made from a relatively young grass having a low crude fibre content in DM: A decrease in the organic matter degradability in an intensively fermented silage was also demonstrated by CATtON et al. (1982).

The content of crude protein in the DM affected significantly the ruminal degradation rate and level of $\mathrm{N}$-free DM and DM, because crude protein was rapidly and to a great extent degraded in the rumen (see Table 3).

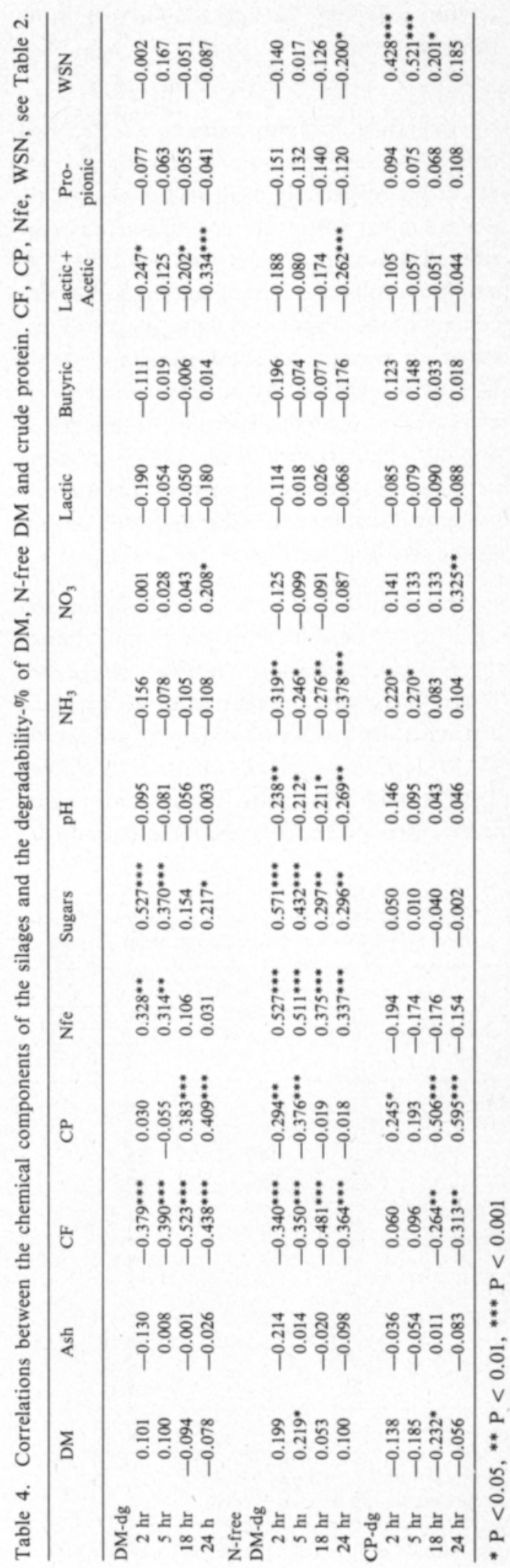


Factors affecting the degradability of crude protein

The crude protein content affected also clearly the degradation of crude protein. The effect was especially clear if the level of the degradability (after 18-24 hours) was considered (also PekKarinen et al. 1983). As similar results were obtained with the $\mathrm{NO}_{3}$ content of the silages it could be suggested that the crude protein content of the silages on the farm was increased by $\mathrm{N}$-fertilization which increases the level of the crude protein degradability (PekKarinen et al. 1983). It seems obvious that, regarding protein degradability, more attention and research should be paid to the use of $\mathrm{N}$-fertilizers for grass.

However, the rate of the degradation was significantly dependent on the proportions of the $\mathrm{NH}_{3}$ and especially WSN in silage (see Table 5), e.g. on the extent of proteolysis and hence on the quality of silage (also BRETT et al. 1981, CAtron et al. 1982). It is known that Clostridia (butyrate fermentation) cause an extensive proteolysis (deamination and de- carboxylation) in the silage (OHshima and McDonald 1978). However, proteolysis can also be caused by heterofermentative lactic acid bacteria, and although this may take place to a limited extend (McDonald 1982), silage which is almost continuously fermented cannot therefore be regarded as a good silage. Moreover, the degradability of silage energy (DM, organic matter) is decreased in an intensively fermented silage.

Crude fibre tended to protect crude protein against digestive processes in the rumen. However, although this is most obviously true, it must be pointed out that while grass matures, the crude fibre content increases and the crude protein content decreases, and this interaction may affect correlation. Moreover, because the ADF-fraction was not determined, it is difficult to say how much ADFbound and hence poorly degradable nitrogen was included in the crude fibre fraction. One can only speculate that the proportion of ADF-N was low because there were not many vigorously fermented silages which may contain larger amounts of ADF-N (GoERING et al. 1972, 1973).

Table 5. Degradability-\% of DM, N-free DM, and crude protein in silages with different WSN contents (WSN = water soluble nitrogen).

\begin{tabular}{|c|c|c|c|c|c|c|c|}
\hline & \multirow{3}{*}{$\begin{array}{c}\text { Incubation } \\
\text { period } \\
\text { hrs }\end{array}$} & \multicolumn{6}{|c|}{ WSN, $\%$ in silage total $\mathrm{N}$} \\
\hline & & \multicolumn{2}{|c|}{$0-39.9$} & \multicolumn{2}{|c|}{$40.0-59.9$} & \multicolumn{2}{|c|}{$60.0-100.0$} \\
\hline & & $\overline{\mathbf{x}}$ & s.d. & $\overline{\mathbf{x}}$ & s.d. & $\overline{\mathbf{x}}$ & s.d. \\
\hline \multirow[t]{4}{*}{ DM } & 2 & 29.8 & 4.6 & 29.9 & 6.1 & 28.5 & 4.6 \\
\hline & 5 & 35.7 & 4.9 & 35.4 & 6.2 & 37.3 & 4.5 \\
\hline & 18 & 59.8 & 4.2 & 57.5 & 6.8 & 58.7 & 8.3 \\
\hline & 24 & 66.1 & 4.9 & 64.3 & 7.5 & 64.7 & 7.0 \\
\hline \multirow[t]{4}{*}{$\mathrm{N}$-free DM } & 2 & 23.4 & 5.6 & 23.2 & 5.7 & 20.4 & 4.3 \\
\hline & 5 & 28.6 & 5.2 & 27.8 & 6.3 & 28.2 & 4.6 \\
\hline & 18 & 48.2 & 3.4 & 46.0 & 5.9 & 46.3 & 5.6 \\
\hline & 24 & 54.0 & 3.7 & 51.6 & 6.3 & 51.5 & 4.6 \\
\hline \multirow[t]{4}{*}{ Crude protein ${ }^{1}$} & 2 & 41.7 & 13.3 & 45.7 & 10.4 & 52.5 & 10.1 \\
\hline & 5 & 46.5 & 14.1 & 51.9 & 8.8 & 59.3 & 7.1 \\
\hline & 18 & 76.2 & 7.5 & 77.0 & 5.6 & 79.0 & 6.8 \\
\hline & 24 & 79.3 & 5.2 & 79.3 & 4.5 & 81.1 & 6.1 \\
\hline $\mathrm{N}$ & & 19 & & 55 & & 17 & \\
\hline
\end{tabular}

1 WSN 0-39.9: $: y=34.07 x^{0.2695}$

WSN 40.0- 59.9: $y=39.76 x^{0.2207}$

WSN $60.0-100.0: y=47.59 x^{0.1730}$

( $y=$ crude protein degradation, $\%, x=$ incubation period, hrs) 
In 3 silages the crude protein degradability was less than $20 \%$ after 2 hours' incubation (see Fig. 1). Any clear explanation for this was not found, as for instance the chemical composition or the quality of these silages did not clearly differ. It is possible that there was an especially strong attack by rumen microbes on feed particles in the bag and in spite of careful washings some microbial material had remained in the bag thus contributing to the amount of nitrogen in the residue of silage. This would cause "lower disappearance» of crude protein from the bag during the incubations.

To conclude, our results indicate that vigorous and long-term fermentations lead to a decreased ruminal degradation (fermentation) of the silage dry matter while the degradability of the crude protein was increased. This was most evident when the degradabilities in the rumen with the first hours after feeding were considered.

Regarding the crude protein degradability, it was not possible to calculate the most appropriate crude protein content of the silage on the basis of the present data. However, it seems relevant to pay attention to the $\mathrm{N}$-fertilization of grass. The maturity of the grass and its importance in this connection should also be considered.

\section{References}

AnoN 1980. Methods of Enzymatic Food Analysis. Boehringer, Mannheim GmbH.

Brett, P.A., Dowson, S. \& Armstrong, D.G. 1981. In sacco degradability of nitrogen in silages made with various additives. Sixth Silage Conf. at Edinburgh, ed. Harkess, R.D. \& Castle, M.E., p. 21-22.

Catton, R., Chamberlain, A.G., Paine, Christine A. \& Crawshaw, R. 1982. In sacco degradability characteristics of two contrasting grass silages. Forage in ruminant animal production ed. Thomson, D.J., Beever, D.E. \& Gunn, R.G. An occasional publ. of the British Soc. of Anim. Prod., p. 175-176.

Goering H.K., Gordon C.H., Hemken R.W., Waldo D.R., VAN Soest, P.J. \& SMIth, L.W. 1972. Analytical estimates of nitrogen digestibility in heat damaged forages. J. Dairy Sci 55: 1275-1280.

-, VAn Soest, P.J. \& Hemken, R.W. 1973. Relative susceptibility of forages to heat damage as affected by moisture, temperature and pH. J. Dairy Sci. 56: 137143.

Heikonen M, Moisio, T. \& Kreula, M. 1979. Assessment of the quality of AIV silage. Valio laboratory publ. 4: $30-56$.

HuidA, L. 1973. Quantitative determination of volatile fatty acids from rumen samples and silage by gas-liquid chromatography. J. Scient. Agric. Soc. Finl. 45: 483488.

Merrez, A.Z. and Ørskov, E.R. 1977. A study of the artificial fibre bag technique for determining the digestibility of feeds in the rumen. J. Agric. Sci., Camb. 88: 645-650.

McDonald, P. 1982. The effect of conservation processes on the nitrogenous components of forages.

Forage protein in ruminant animal production, ed. Thomson, D.J., Beever, D.E. \& Gunn, R.G. An occasional publ. of the British Soc. of Anim. Prod., p. 41-49.

Miller, E.L. 1982. The nitrogen needs of ruminants. Forage protein in ruminant animal production, ed. Thomson, D.J., Beever, D.E \& Gunn, R.G. An occasional publ. of the British Soc. of Anim. Prod., p. 79-87.

Ohshima, M. \& McDonald, P. 1978. A review of the changes in nitrogenous compounds of herbage during ensilage. J. Sci. Fd. Agric. 29: 497-505.

Pekkarinen, E., Syrjālä-Qvist, L. \& Setãlā, J. 1983. Klöver/timotejförhållandets och timotejs kvävegödselmăngdens inverkan på proteinet $\mathrm{i}$ ensilage. 17. NJFmötet i Helsingfors, in press.

SetÁlĀ, J. 1983. The nylon bag technique in the determination of ruminal feed protein degradation. J. Scient. Agric. Soc. Finl. 55: 1-78.

- 1984. Preparation of grass silage in Finland and its feeding to dairy cows. Mötet i Uppsala av »Ensileringsformer samt värderingsnormer i ensileringsförsök», 2. 4. $1984,16 \mathrm{p}$.

SoмоGyı, M. 1945. A new reagent for the determination of sugars. J. Biol. Chem. 160: 61-68.

Tномаs, P.C. 1982. Utilization of conserved forages. Forage protein in ruminant animal production, ed. Thomson, D.J., Beever, D.E. \& Gunn, R.G. An occasional publ. of the British Soc. of Anim. Prod., p. $67-76$.

Ms received February 28, 1985 


\section{SELOSTUS}

\section{Säilörehun kuiva-aineen ja raakavalkuaisen in sacco -hajoavuuteen vaikuttavat tekijät}

\section{Jouko Setälä1, Alem Tesfa²,}

Aino Rauramaa' ${ }^{1}$ ja Esko Poutiainen ${ }^{3}$

1 Valion tutkimus- ja tuotekehittelyosasto, Kalevankatu 56 B, PL 176, 00181 Helsinki

2 Helsingin yliopisto, Kotieläintieteen laitos, 00710 Helsinki

${ }^{3}$ Maatalouden tutkimuskeskus, 31600 Jokioinen

Tutkimuksessa käytetyt 96 säilörehua kerättiin suoraan maatiloilta eri puolilta Suomea. Năytteet kuljetettiin ja varastoitiin pakastettuina. Kuiva-aineen ja raakavalkuaisen pötsihajoavuus mäăritettiin nailonpussi-menetelmällă kãyttămaallă koe-eläimină kahta pőtsifistelooityă lammasta, jotka olivat săilörehu-heinä-ruokinnalla ( $50: 50$ kuiva-aineen perusteella).

Säilörehussa olevat typettömăt uuteaineet lisăsivăt ja raakakuitu văhensi kuiva-aineen hajoavuutta pötsissă korrelaatioanalyysien mukaan arvioituna. Yleisesti tarkas- teltuna säilörehun kăymistuotteiden korrelaatio kuivaaineen hajoavuuteen oli negatiivinen.

Săilörehun raakavalkuais- ja $\mathrm{NO}_{3}$-sisältő korreloituivat positiivisesti raakavalkuaisen hajoamisasteeseen pötsissă. Săilörehussa tapahtunut proteolyysi $\left(\mathrm{NH}_{3}^{-}\right.$, liukoisen typen määrä) lisäsi puolestaan raakavalkuaisen hajoamisnopeutta. Rehun raakakuitupitoisuuden ja raakavalkuaisen hajoavuuden vălisen negatiivisen korrelaation perusteella raakakuidulla oli hajoavuutta văhentävă vaikutus. 